\title{
NUTRITIONAL VALUE OF TRADITIONAL AND MODERN MEALS: JORDAN AND HUNGARY
}

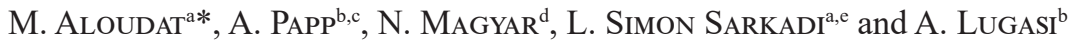 \\ ${ }^{a}$ Doctoral School of Food Science, Faculty of Food Science, Szent István University, \\ H-1118 Budapest, Villányi út 29-43. Hungary \\ ${ }^{b}$ Department of Hospitality, Faculty of Commerce, Hospitality and Tourism, Budapest Business School, H-1054 \\ Budapest, Alkotmány utca 9-11. Hungary \\ ${ }^{\mathrm{c}}$ Doctoral School of Nutrition and Food Science, University of Debrecen, H-4032 Debrecen, Egyetem tér 1. \\ Hungary \\ ${ }^{\mathrm{d}}$ Department of Methodology for Business Analysis, Faculty of Commerce, Hospitality and Tourism, Budapest \\ Business School, H-1054 Budapest, Alkotmány út 9-11. Hungary \\ ${ }^{e}$ Department of Food Science and Nutrition, Faculty of Food Science, Szent István University, H-1118 Budapest, \\ Somlói út 14-16. Hungary
}

(Received: 27 April 2020; accepted: 6 July 2020)

The purpose of this study was to compare the energy content and macronutrients of forty main popular traditional and modern meals in both Jordan and Hungary with the national and international recommendations. The calculation of energy content and macronutrients were done on traditional and modern recipes by two different softwares (ESHA and NutriComp). Neither Jordanian nor Hungarian foods met the recommended energy content ( $35 \%$ of daily energy intake, $8400 \mathrm{~kJ}$ for energy intake). The recipes of both nations are characterised by higher protein, fat, and salt contents than WHO recommendation, a lower fibre content, and sugar content within the recommended limits. The fat energy ratio and saturated fatty acid content of Hungarian recipes are significantly higher than WHO recommendation. In general, Jordanian meals were more likely to meet the inclusion criteria. In conclusion, neither Jordanian nor Hungarian traditional and popular meals meet the international nutritional recommendations for a healthy diet, however, the composition of the real dishes may differ significantly from the recipes depending on the available ingredients and chosen kitchen technology.

Keywords: traditional meal, nutritional content, nutritional software, Jordan, Hungary

According to the World Health Organisation, in 2016 more than 1.9 billion adults ( $\geq 18$ years) were overweight, 650 million of these adults were obese (WHO, 2018). In Jordan, an overall prevalence rate of $30.5 \%$ overweight and $35.9 \%$ obesity among the Jordanian population was reported in 2018 (MINISTRY OF HEALTH OF JORDAN, 2018). In Hungary, RURIK and co-workers (2016) reported an overall prevalence rate of overweight and obesity among men as $40 \%$ and $32 \%$, respectively, while overweight and obesity occurred in $32 \%$ of women based on data from $0.55 \%$ of the population above 18 year (43 287 persons) (RURIK et al., 2016). The latest Hungarian representative dietary survey (OTÁP, 2014) shows that nearly two-thirds of adults are overweight or obese (ERDEI et al, 2017).

Energy imbalance is one of the main causes of obesity. Globally, there has been an increased intake of energy-dense foods. In the Jordanian population, the proportion of energy from fat, carbohydrate, and protein is within the recommended value (ALKURD et al. 2019), the daily fibre intake is $8 \mathrm{~g} / 1000 \mathrm{kcal}$ and that for sodium is $7623 \mathrm{mg}$ (ALKURD, 2011). In the

\footnotetext{
* To whom correspondence should be addressed.

E-mail: MohannadM.AlOudat@gmail.com
} 
Hungarian population, the proportion of energy intake from fat is higher and from carbohydrate is lower than the recommended value, the protein intake is adequate, the average fibre intake is $22.9 \mathrm{~g}$ /day (SARKADI NAGY et al., 2017) and the sodium intake is $5300 \mathrm{mg} /$ day (NAGY et al., 2017).

A huge part of our food intake comes from traditional meals and modern meals requiring traditional ingredients that are popular among people. They are frequently consumed in every country, because it is a defining part of the national cuisine. So far, there are limited studies published on the healthiness of these meals.

HowARD and co-workers (2012) studied the energy and macronutrient contents of 100 main meal recipes of five popular UK television chefs. Authors compared the nutrient contents of these meals both with the WHO nutritional recommendations and UK Food Standards Agency's (FSA) "traffic light" system for labelling food. They found that no recipe fully complied with the WHO recommendations.

SCHNEIDER and co-workers (2013) investigated the nutritional properties of recipes (entrees and main dishes) shared on popular online food blogs. The nutritional values of the meals were analysed according to US Dietary Guidelines. The recipes analysed in this study met energy recommendations but were excessive in saturated fat and sodium.

In a cross sectional study, TRATTNER and co-workers (2017) compared the energy and macronutrient contents of 5237 main meal recipes from the food website Allrecipes.com with those of 100 main meal recipes from popular chefs and 100 ready meals. The basis of the comparison was also the nutritional guideline published by WHO and recommendation of FSA. Only six from 5237 internet recipes fully complied with the WHO recommendations. Internet recipes were more likely to meet the WHO guidelines for protein than other classes of meal, however, these recipes were less likely to meet the criteria for fat, saturated fat, and fibre compared to ready meals. More internet recipes met the criteria for sodium density than ready meals, but fewer than the popular chef meals.

TRATTNER and co-workers (2017) investigated the healthiness of 58720 recipes from internet website of Allrecipes.com. Their main finding was that only a small percentage of recipes available on the internet can be considered healthy according to WHO and FSA guidelines. The healthiness of recipes varied across the 27 different meal categories, but even recipes in the "healthy recipes" category can be misleading.

Recipes promoted either in books, websites, or TV programmes by popular chefs are sometimes presented as being healthy. Therefore, in this study, we compared the energy, macronutrients, fibre, and sodium contents of the main and popular traditional and modern meals in both Jordan and Hungary with the national and international recommendations.

\section{Materials and methods}

\subsection{Selection of recipes}

The selection of the main dishes' recipes was randomised. A meal was considered a "traditional meal" if all the ingredients and preparation methods in the recipe were mainly traditional as known to the people from the same nation. If some of its ingredients and kitchen techniques or machines were not considered traditional by the people from the same nation and its style and ingredients are similar to those popular among restaurants nowadays, it was considered a "modern meal" (e.g. the usage of Indian curry as ingredient, sous-vide as technique, or pacojet as device).

Acta Alimentaria 49, 2020 
A main meal was considered as a meal consumed at lunch as a main course. Soups were excluded, because they are not always consumed as main dishes. Side and sweet dishes were also excluded. In case the main course was usually consumed with a side dish, the side dish was included. Meals included had no special dietary restriction as gluten-free, lactose-free, sugar-free, decreased carbohydrate content, and so on.

The Jordanian recipes $(n=40)$ were collected from the website of a famous and popular Jordanian chef, Manal Alalem**. The recipes on this Arabic-language website also included videos that illustrated the kitchen techniques well. The processes presented in the videos were occasionally necessary and useful in nutrient calculations.

The Hungarian recipes $(n=40)$ were collected from three popular traditional cookbooks and one book containing novel recipes: i) The traditional Hungarian kitchen (HoRvátH, 2010), ii) Flavours of Hungary (UNGER, 1994), iii) New Hungarian cookbook (KALLA, 1998), and iv) Best recipes from Budapest Business School (edited by Lugasi, 2019).

\subsection{Nutritional analysis}

Two different software were used to calculate the energy (kcal, kJ), carbohydrate $(\mathrm{g})$, protein $(\mathrm{g})$, fat $(\mathrm{g})$, fibre $(\mathrm{g})$, and sodium (mg) contents in one serving for each meal based on the raw ingredients declared in the recipes. One was ESHA Food Processor ${ }^{\circledR}$ Nutrition Analysis, an international software that utilises an extensive and detailed food and ingredient database. The other software was a Hungarian software called NutriComp DietCAD, developed for dieticians and nutritionists, with a nutrition planning program, and having a comprehensive database of food raw materials with nearly 1600 food contents and a wide range of nutrients.

When the ingredient of a meal was not found in the software, it was substituted with the nearest available item. If no item was suitable for replacement, the nutritional content was manually inserted. All ingredients were inserted in grams to eliminate the difference in the weight of ingredients in the two software.

\subsection{Statistical analysis}

For each meal, the nutritional content per one serving was calculated by dividing the total content by the number of servings in the meal's recipe.

There is no specific recommendation as to how much energy from each meal should be included in the energy intake of the entire daily diet. In this study, the Hungarian legislation on public catering was considered as a reference when evaluating the energy content of a main course (37/2014. [IV. 30.] Ministerial Decree, Ministry of Human Capacities of Hungary, 2014). According to this, the energy content of a main course accounts for $35 \%$ of the total daily energy intake. In the regulation 1169/2011 of the European Parliament and of the Council, the daily reference intake for energy is $8400 \mathrm{~kJ}$ or $2000 \mathrm{kcal}$ for adults (EU, 2011). When evaluating the energy content of main dishes, $35 \%$ of this recommended energy intake, i.e. $700 \mathrm{kcal}$, was used as reference.

Using Wilcoxon-test, the percentage of energy from meals was compared to $700 \mathrm{kcal}$, and the energy percentage derived from macronutrients in the meals was compared with the nutrient intake goals recommended by WHO (WHO, 2003) to prevent diet related chronic diseases.

\footnotetext{
** see more information on Manal Alalem: https://www.food4ever.org/person/chef/manal-alalem/
} 
All statistical analyses were done by using R software, which is a programming language and free software environment for statistical computing and graphics (R CORE TEAM, 2017).

\section{Results and discussion}

\subsection{Nutrients in Jordanian meals referring to the recommendations}

Table 1 shows the median percentage of energy from meals, energy percentage derived from macronutrients, as well as fibre and sodium density for Jordanian meals. No Jordanian meals met all nutritional recommendations. It also shows the number of meals that met each nutrient specific WHO recommendation.

According to Table 1, no Jordanian meal met the energy percentage for lunch. From 40 meals, $24(60 \%)$ had smaller, $16(40 \%)$ meals higher energy content than 700 kcal calculated by ESHA software, while the numbers were 25 (62.5\%) and $15(37.5 \%)$ when nutrients were calculated by NutriComp software. Result indicated that energy content of main dishes were rather smaller than the recommended value.

However, no significant difference could be observed in relation to recommended value, because there were meals with higher and lower energy contents as well. The deviation from recommendation is not one-way. $\mathrm{P}$ values in Table 1 demonstrate that carbohydrate content of Jordanian meals are significantly lower than the lower end of the recommendation, while sugar contents meet the recommendation of less than 10 energy $\%$. Protein content of meals is significantly higher than 15 energy $\%$. Fat content is significantly higher than the upper end of the recommendation, and the energy originated from saturated fatty acids is more than the scientifically acceptable level.

For the comparability, a special index for sodium and dietary fibre data was developed by HowARD and co-workers (2012). Based on international recommendations, an intake of 25 $\mathrm{g}$ of dietary fibre is recommended with an energy content of $8.4 \mathrm{MJ}$, which means that more than $3 \mathrm{~g}$ of dietary fibre per one MJ energy is advised. Based on data calculated from recipes, Jordanian meals do not meet this condition. In case of sodium content, the limit of the special index is $0.2 \mathrm{~g} / \mathrm{MJ}$, which means that values higher than this do not comply with the international sodium intake recommendation. The sodium content of Jordanian meals does not meet the criteria either.

The assumption that justifies the differences between the two software is the variety of nutrients in the database; the fact that the nutrient levels vary according to geographical location, growing conditions, environment, harvest, preparation, and analysis methods of food present in Food Composition Tables that are used as database in such software (AsSUnÇão et al, 2017).

\subsection{Nutrients in Hungarian meals referring to the recommendations}

Table 2 shows the median percentage of energy from meals, energy percentage derived from macronutrients, as well as fibre and sodium densities for Hungarian meals. No Hungarian meals met all nutritional recommendations. Table 2 also shows the number of meals that met each nutrient specific WHO recommendation. No Hungarian meal met the energy percentage for lunch. From 40 meals, $11(27.5 \%)$ had smaller, 29 (72.5\%) had higher energy content than $700 \mathrm{kcal}$ calculated by ESHA software, while the numbers were $15(37.5 \%)$ and 25 $(62.5 \%)$ when nutrients were estimated by NutriComp software.

Acta Alimentaria 49, 2020 
ALOUDAT et al.: NUTRITIONAL VALUE OF MEALS: JORDAN AND HUNGARY
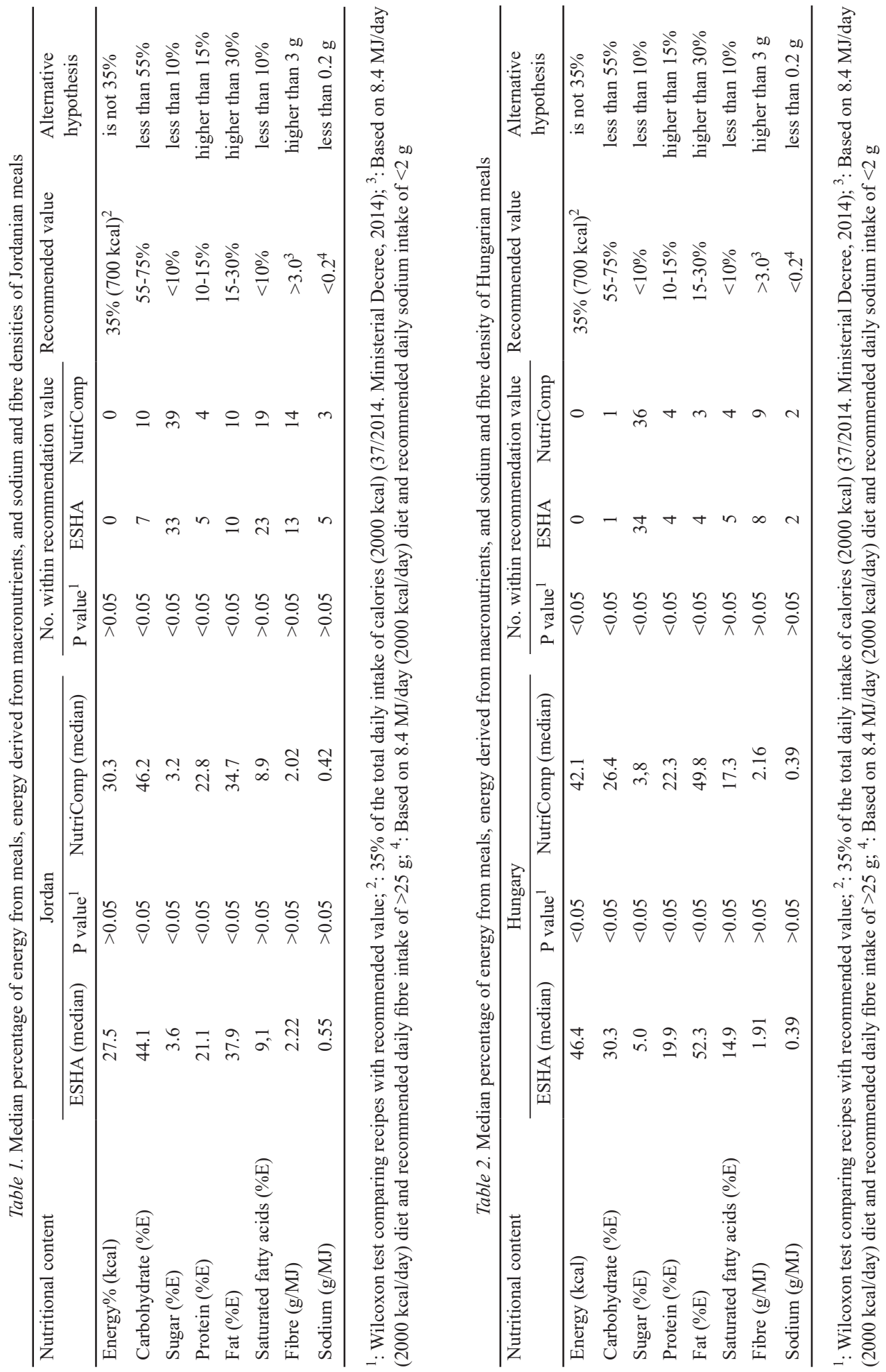

Acta Alimentaria 49, 2020 
When examining the median of energy content calculated by both ESHA and NutriComp software, the deviation from the recommendation is significant, i.e. the energy content of Hungarian foods is significantly higher than the recommended $35 \mathrm{E} \%$. This phenomenon is contrary to what was found for Jordanian food. The carbohydrate and the sugar energy ratio of the main dishes was significantly lower than the lower limit of the recommended value. The energy ratios of the protein and fat content of the main dishes was significantly higher than the upper limit of the recommendation. In the case of saturated fatty acids, fibre, and sodium the median did not significantly differ from the recommendation. Except for energy, the nutrients deviate as much and in the same direction from the recommendation in Hungarian dishes than in Jordanian ones.

\section{Conclusions}

Popular recipes both from Jordan and Hungary tended to be high in protein, fat, and sodium and low in carbohydrate and fibre contents and were within the recommended range for sugar according to WHO nutritional guidelines for the avoidance of diet related diseases. Hungarian meals were also high in energy and saturated fatty acids. In conclusion, neither Jordanian nor Hungarian meals complied with the nutritional recommendations published by WHO. In general, Jordanian meals were more likely to meet the inclusion criteria than Hungarian meals.

This study is the first to explore the nutritional content of national recipes based on different gastronomy tradition, dietary habit, raw material selection, and cuisine technique. To increase the validity of our findings, a populist sampling system was used to select both Jordanian and Hungarian recipes. Nevertheless, the nutritional content of recipes varied significantly between individual cookbooks and chef's websites, meaning that a different selection process may have resulted in different results.

The WHO recommendations used are based on average daily intake of main nutrients rather than on individual meals, and it is not necessary for a main course to meet these standards. In the absence of international recommendations on the nutrient content of individual foods, WHO standards are the most scientifically acceptable and have previously been used by other authors to analyse the nutritional values of individual foods (HowARD et al., 2012; TrATTNER et al., 2017).

Meals and their preparation techniques in old or newly published cookbooks and popular chef's websites do not represent de facto home cooking practices. Preparing meal at home might be different, since people cook without recipes, use recipes from other sources, or prepare meals containing substituted elements. The true nutritional value of foods prepared and consumed by humans can be significantly influenced by available food ingredients, national gastronomic traditions, new trends, as well as popular cooking methods.

Authors would like to thank the Hungarian Government represented by Ministry of Foreign Affairs and Trade and the Tempus Public Foundation for Stipendium Hungaricum scholarship program and the Doctoral School of Food Science at Szent István University for covering the software cost and providing the necessary support.

\section{References}

AlKuRD, R.A. (2011): Estimated intakes of fats, cholesterol, fibre, sodium, calcium, potassium and magnesium in Jordan. Aust. J. Basic Appl. Sci., 5(12), 3171-3178.

Acta Alimentaria 49, 2020 
Alkurd, R., TAkruri, H.R. \& Amr, A.M. (2019): Trends of energy and macronutrients intakes in Jordan as obtained by household expenditure and income surveys. J. Agr. Sci., 11(1), 191-199.

Assunção, L.B., Schincaglia, R.M., Trindade, B.D.B., Correia, M.H.S. \& Peixoto, M.R.G. (2017): Comparing nutritional value of diets among nutrition software. J. Health Inform. 9(3), 81-86.

Erdei, G., Kovács, V.A., BaKacs, M. \& Martos É. (2017): Országos Táplálkozás és Tápláltsági Állapot Vizsgálat 2014. I. A magyar felnőtt lakosság tápláltsági állapota. [Hungarian Diet and Nutritional Status Survey 2014. I. Nutritional status of the Hungarian adult population]. Orvosi Hetilap, 158(14), 533-540.

ESHA RESEARCH: https://esha.com (last accessed: 30 March 2020)

EU (2011): Regulation (EU) No 1169/2011 of the European Parliament and of the Council of 25 October 2011 on the provision of food information to consumers. Off. J. EU, L 304/18

Horvítr, I. (2010): The traditional Hungarian kitchen, Vince Publisher, Budapest, 96 pages.

Howard, S., Adams, J. \& White, M. (2012): Nutritional content of supermarket ready meals and recipes by television chefs in the United Kingdom: Cross sectional study. BMJ, 345:e7607

Kalla, K. (1998): Gundel new Hungarian cookbook. Pallas Studio Publisher, Budapest, 194 pages.

LugASI, A. (ED) (2019): Ínyencségek a múltból és a jelenből. A BGE-KVIK legjobb receptjei. (Delicacies from the past and the present. Best recipes from Budapest Business School Faculty of Commerce, Hospitality and Tourism), Budapesti Gazdasági Egyetem, Kereskedelmi, Vendéglátóipari és Idegenforgalmi Kar, 86 pages.

Manal Alalem's website. Available at: https://www.manalonline.com/ (last accessed 27 March 2020)

Ministry of Health of JoRdan (2018): The Ministry of Health in Figures, p. 18. Available at: https://www.moh. gov.jo/Echobusv3.0/SystemAssets/435a78d7-40c2-46fe-937f-8694b5a5a8d1.pdf (last accessed 13 April 2020)

Ministry of Human Capacities of Hungary (2014): 37/2014. (IV. 30.) Ministerial Decree of Ministry of Human Capacities on nutritional standards in public catering. http://njt.hu/cgi_bin/njt_doc.cgi?docid=169011.268148 (last accessed 30 March 2020)

Nagy, B., Nagy-Lőrincz, Zs., BaKacs, M., Illés, É., SArkadi Nagy, E. \& Martos, É. (2017): Országos Táplálkozás és Tápláltsági Állapot Vizsgálat - OTÁP2014. III. A magyar lakosság makroelem-bevitele (Hungarian Diet and Nutritional Status Survey - OTÁP2014. III. Macroelement intake of the Hungarian population). Orvosi Hetilap, 158(17), 653-661.

NuTRICOMP DiET CAD: https://www.nutricomp.hu

R Core TеAm (2017): R: A language and environment for statistical computing. R Foundation for Statistical Computing, Vienna, Austria. https://www.r-project.org/ (last accessed: 20 March 2020)

Rurik, I., Ungvári, T., Szidor, J., Torzsa, P., Móczár, Cs., ... \& SÁndor, J. (2016): Elhízó Magyarország. A túlsúly és az elhízás trendje és prevalenciája Magyarországon, 2015. (Obese Hungary. Trend and prevalence of overweight and obesity in Hungary, 2015.) Orvosi Hetilap, 157(31), 1248-1255.

Sarkadi Nagy, E., Bakacs, M., Illés, É., Nagy, B., Varga, A., Kis, O.S., Molnár, E. \& Martos, É. (2017): Országos Táplálkozás és Tápláltsági Állapot Vizsgálat - OTÁP2014. II. A magyar lakosság energia- és makrotápanyag-bevitele (Hungarian Diet and Nutritional Status Survey - OTÁP2014. II. Energy and macronutrient intake of the Hungarian population). Orvosi Hetilap, 158(15), 587-597.

Schneider, E.P., McGovern, E.E., Lynch, C.L. \& Brown, L.S. (2013): Do food blogs serve as a source of nutritionally balanced recipes? An analysis of 6 popular food blogs. J. Nutr. Educ. Behav., 45(6), 696-700.

TrattNer, C., Elsweiler, D. \& Howard, S. (2017): Estimating the healthiness of internet recipes: A cross-sectional study. Front. Public Health, 5:16., 10 pages

Unger, K. (1994): Flavours of Hungary. Grafo Publisher, Budapest, 127 pages.

WHO (2003): Population nutrient intake goals for preventing diet-related chronic diseases. Diet, nutrition and the prevention of chronic diseases. Available at: https://www.who.int/nutrition/topics/5_population_nutrient/en/ (last accessed: 27 March 2020)

WHO (2018): Obesity and overweight. Available at: https://www.who.int/news-room/fact-sheets/detail/obesity-andoverweight (last accessed: 26 March 2020)

Open Access statement. This is an open-access article distributed under the terms of the Creative Commons Attribution 4.0 International License (https://creativecommons.org/licenses/by/4.0/), which permits unrestricted use, distribution, and reproduction in any medium, provided the original author and source are credited, a link to the CC License is provided, and changes - if any - are indicated. (SID_1) 